\title{
EVOLUÇÃO DA DÍVIDA PÚBLICA NO ESTADO DE MATO GROSSO NO PERÍODO DE 2002 A 2012: ANÁLISE SOBRE A SUSTENTABILIDADE FINANCEIRA
}

\author{
Danieli Artuzi Pes Backes ${ }^{1}$ \\ Eduardo Matsubara ${ }^{2}$
}

\begin{abstract}
RESUMO
O presente artigo se propôs a verificar o comportamento da dívida pública do estado de Mato Grosso no período entre 2002 a 2012. Para atingir este propósito, foram levantados os valores referente a dívida pública, ao Produto Interno Bruto (PIB), a Receita Corrente Líquida $(\mathrm{RCL})$ e ao resultado primário do estado no período; calculado o percentual da dívida em relação ao PIB e a RCL; e à sustentabilidade da dívida pública ao longo do período. O método adotado tomou como base o modelo de Pasinetti (1998) e se utilizou de sítios eletrônicos tais como Instituto Brasileiro de Geografia e Estatística (IBGE), da Secretaria de Estado de Fazenda (SEFAZ-MT), da Secretaria de Estado de Planejamento e Coordenação Geral (SEPLAN-MT) para a coleta de dados. A base teórica apresenta o conceito de accountability, sua relação com as finanças públicas e sua aplicação na Lei de Responsabilidade Fiscal (LRF). Após a organização e análise preliminar dos dados por meio de estatística descritiva, constatou-se que tanto a relação dívida pública/PIB quanto a relação dívida pública/RCL apresentaram uma significativa redução, apontando para uma trajetória sustentável. Visando a análise confirmatória, foi aplicado o modelo de Pasinetti, que corroborou com os resultados encontrados nas análises preliminares.
\end{abstract}

Palavras-chave: Dívida Pública; sustentabilidade; Mato Grosso

\section{THE EVOLUTION OF PUBLIC DEBT IN MATO GROSSO STATE THE PERIOD 20022012}

\begin{abstract}
This article investigated the behavior of public debt of the state of Mato Grosso in the period 2002 to 2012. To achieve this purpose, the values related to public debt were raised, the Gross Domestic Product (GDP), the Current Net Revenue $(R C L)$ and the primary result of the state in the period; calculated the percentage of debt to GDP and the RCL; and inferred as the sustainability of public debt over the period. The methodology used the techniques of literature and documentary research to survey the necessary information. The theoretical basis introduces the concept of accountability, its relationship with the public finances and its application in the Fiscal Responsibility Law (FRL). The object of the study data were obtained on the Internet sites of the Brazilian Institute of Geography and Statistics (IBGE), the Secretary of State of Finance (SEFAZ-MT), the Secretary of State for Planning and General Coordination (SEPLAN-MT). After organizing
\end{abstract}

\footnotetext{
${ }^{1}$ Doutoranda em Administração pela Uninove. Professora Adjunto I do Departamento de Administração da UFMT. Leciona e possui interesse nos seguintes temas: Estratégia, Gestão Ambiental, Gestão Pública e Pesquisas no ensino superior. E-mail:backes.dani@gmail.com.

${ }^{2}$ Graduado em Economia e Administração pela Universidade Federal de Mato Grosso. Economista na Secretaria de Planejamento do Estado do Mato Grosso.
}

Revista de Estudos Sociais | Ano 2017, N. 39, V. 20, Pag. 88 
and preliminary analysis of the data it was found that both the public debt / GDP and the public debt / RCL had a significant decrease, indicating to a sustainable path. To check for sustainability, it applied the theoretical model of Pasinetti. The results corroborate the statement of the preliminary analysis.

Keywords: Public Debt; Gross Domestic Product; Net Current Revenue; Mato Grosso.

\section{INTRODUÇÃO}

Com a redemocratização do país, a partir da Constituição de 1998, os estados se fortaleceram institucionalmente e passaram a ter uma maior autonomia financeira. Entretanto, o processo não foi bem definido e nem mecanismos de controle fiscais efetivos foram criados. Neste contexto, os estados e municípios passaram a se endividar contando que a União os socorreria, o que de fato ocorreu por diversas vezes, gerando negociações que nem sempre foram cumpridas pelos estados. Até 1994, o chamado "imposto inflacionário" gerava receitas extras para os estados, tanto pelos reajustes salariais do funcionalismo abaixo do índice de inflação, quanto pelo atraso no pagamento dos credores. Porém, com a estabilização dos preços, os estados perderam as receitas extras geradas pelo "imposto inflacionário" e ficou evidente a situação crítica nas contas públicas estaduais.

A crise financeira dos estados motivou uma ampla renegociação dessas dívidas, que acabaram por ser assumidas pela União. Porém, desta vez com maiores garantias de seu pagamento e incluindo uma série de compromissos assumidos pelos estados. Entretanto, ainda faltavam os meios de punição dos gestores públicos que não cumprissem as regras estabelecidas. Neste sentido, em maio de 2000 foi aprovada a Lei de Responsabilidade Fiscal (LRF) com a exigência do equilíbrio fiscal em todas as esferas de governo. Em busca da estabilidade, esta lei estabeleceu metas anuais a serem perseguidas pela administração pública. O seu descumprimento poderia acarretar sanções institucionais como retenção de transferências constitucionais e a proibição de contratação de empréstimos e convênios com o Governo Federal. O agente público ainda estaria sujeito a sanções pessoais previstas no código penal como cassação de mandato, inabilitação para exercer função pública, multa e detenção, que poderia variar entre 6 meses e 4 anos.

Com o advento da Lei de Responsabilidade Fiscal (LRF) em maio de 2000 (LOUREIRO; ABRUCIO, 2004), o equilíbrio fiscal passou a ser a maior preocupação dos gestores públicos e as finanças públicas passaram a receber atenção especial em todas as esferas de governo. Os estados foram forçados a gerar superávit primário, necessário para garantir o pagamento dos juros da dívida pública. Como consequência houve significativa redução dos recursos que poderiam ser destinados a investimentos nas áreas básicas do governo. Quando a União assumiu as dívidas dos estados, de acordo com a Lei no 9.496/97, as negociações foram individuais, sendo que cada unidade federativa recebeu tratamento diferenciado de acordo com seu nível de endividamento (MORA, 2002). O estado de Mato Grosso, na época, não possuía economia de destaque nacional e o valor da dívida pública atingia patamares muito elevados.

Nos últimos anos o estado ganhou importância econômica, principalmente devido à ascenção do agronegócio, que o tornou referência internacional de 
produtividade, proporcionando volume elevado de exportação, que garante 0 equilíbrio da balança comercial brasileira (BARROS; SILVA, 2008). Assim, em busca de compreender a trajetória geradora de receita do estado em relação ao nível de endividamento e considerando o arcabouço legal sob o qual se buscou - equilíbrio orçamentário e a gestão fiscal responsável, questiona-se: o comportamento da dívida pública do Estado de Mato Grosso apresenta sustentabilidade financeira?

A principal hipótese é de que com os mecanismos implementados pela LRF, que busca restringir o endividamento do setor público e pressionar para a obrigação quanto à geração de economias para o pagamento dos juros da dívida pública, o peso do endividamento de estado de Mato Grosso tenha diminuído paulatinamente o seu peso tanto em relação ao Produto Interno Bruto (PIB), quanto em relação à Receita Corrente Líquida $(\mathrm{RCL})$.

O estudo proposto tem como objetivo analisar a evolução da dívida pública do Estado de Mato Grosso após a entrada em vigor da LRF, tomando como base o período de 2002 a 2012, no intuito de verificar sua sustentabilidade. Para atingir este propósito, foram levantados os valores referentes à dívida pública, ao PIB, a RCL e ao resultado primário do estado no período. As etapas posteriores consistiram em avaliar o percentual da dívida em relação ao PIB e a RCL, de modo a verificar a sustentabilidade da dívida pública ao longo do período.

A relevância deste estudo reside em apresentar um diagnóstico que contribuirá com a discussão teórica de Finanças Públicas no que se refere à análise da dívida pública dos estados, por meio de pesquisa empírica. O assunto é de tal importância que voltou à pauta de discussões políticas e econômicas nos últimos dois anos, devido à grave crise fiscal enfrentada pelos estados brasileiros, ocasião na qual começou a ser discutida a reforma da previdência (PREVIDÊNCIA, 2017). Os gastos com pessoal, especialmente os inativos e pensionistas foi apontada como a principal causa para o desequilíbrio orçamentário dos estados (FIRJAN, 2017).

O comprometimento estrutural previdenciário dos estados brasileiros, que segundo o FMI cresceu em média 50\% entre 2009 e 2015 (FMI, 2016), tem limitado os investimentos e deixado as unidades federativas à mercê da crise econômica, que gerou redução de arrecadação e expôs a situação crítica dos estados em relação às despesas com pessoal, que em alguns casos extrapola - limite máximo estabelecido pela Lei de Responsabilidade Fiscal, de 60\% (FIRJAN, 2017). Portanto, o estudo também apresenta implicações práticas, de modo que a demonstração do comportamento da dívida colabora com a transparência e aumenta a confiança quanto às perspectivas econômicas do estado, além de permitir ao cidadão visualizar o modo como o governo tem alocado seus recursos arrecadados.

Após esta introdução, será apresentada a base teórica, ancorada em Finanças Públicas, Dívida Pública, Accountability nas Finanças Pública, autonomia e responsabilização dos entes federativos, Lei de Responsabilidade Fiscal. A seguir serão explanados os procedimentos metodológicos e o método empregado para avaliação da sustentabilidade da dívida pública, o modelo de Pasinetti (1998). Na quarta seção, são apresentados os resultados obtidos e por fim, na quinta seção, serão tecidas as considerações finais.

\section{FINANÇAS PÚBLICAS E RESPONSABILIDADE FISCAL}

Revista de Estudos Sociais | Ano 2017, N. 39, V. 20, Pag. 90 
Finanças Públicas são definidas por Viceconti (2002, p. 385) como "o ramo da Teoria Econômica que trata das receitas e despesas governamentais". Em uma definição mais abrangente, Sandroni (2001) afirma que as finanças públicas podem ser compreendidas como o campo que controla o montante de recursos financeiros e créditos transacionados pelo governo nacional e seus entes.

O instrumento pelo qual a Administração Pública planeja suas atividades, a partir dos recursos financeiros disponíveis recebe o nome de Orçamento Público. Este estabelece as prioridades de atendimento às demandas sociais, considerando que as despesas só podem ser executadas pelo gestor público se esta estiver prevista no orçamento. Dessa, forma seu papel vai além do planejamento e abarca atividades de controle.

Em uma conceituação mais voltada aos aspectos econômico-legais, Sandroni (2001) afirma que o Orçamento Público tradicionalmente se refere à estimativa monetária de entradas e saídas dos cofres governamentais. $O$ orçamento público está atrelado ao planejamento governamental. Este, deve prever a origem dos recursos e o montante a ser arrecadado, assim como a natureza e as decisões quanto aos dispêndios com ações e projetos a serem executados, em qualquer uma das esferas do governo (PISCITELLI, 2009). Os objetivos da elaboração do orçamento público governamental se referem a: a) alocação adequada de recursos; b) promoção de distribuição de renda e; c) manutenção do equilíbrio econômico (VICECONTI, 2002).

Para construção e aprovação legal do Orçamento Público é necessária a previsão de todas as receitas e fixação de todas as despesas públicas. A Receita Pública (RP) representa a totalidade de impostos, taxas, contribuições e outras fontes de recursos, arrecadados para atender às necessidades públicas. De acordo com o Banco Central do Brasil (2008), a RP diz respeito às entradas orçamentárias não recuperáveis para custeio das despesas públicas.

Por outro lado, a Despesa Pública (DP) é a somatória de todos os gastos governamentais definidos de acordo com as prioridades estabelecidas pelos governos. Para Baleeiro (1996, p. 65) é "o conjunto dos dispêndios do Estado, ou de outra pessoa de direito público, para o funcionamento dos serviços públicos". Ratificando o conceito, Riani (2002, p. 79) define a Despesa Pública como "...uma escolha política dos governos no que se refere aos diversos serviços que eles prestam à sociedade. Representam o custo da quantidade $\mathrm{e}$ da qualidade dos serviços e bens oferecidos pelo governo. "

Quando as despesas do governo superam as receitas temos como resultado o chamado déficit orçamentário. Quando, ao contrário, observamos uma receita superior à despesa temos o superávit orçamentário (SANDRONI, 2001, p. 583). Quando ocorre o déficit orçamentário, o governo para financiar suas atividades, pode utilizar três instrumentos distintos: a) aumentar a arrecadação de tributos, b) emitir moeda ou, c) vender títulos da dívida pública (RIANI, 2002, p. 133). Dentre essas alternativas, porém, somente a evolução da dívida pública será tratada nesse tópico, pelo fato de ser o objeto de interesse dessa pesquisa.

\subsection{Dívida Pública}

Revista de Estudos Sociais | Ano 2017, N. 39, V. 20, Pag. 91 
A Dívida Pública (DP) é o conjunto de obrigações contraídas pelo governo com o objetivo de atender a gastos não suportados pela receita tributária ou ainda no financiamento de empreendimentos de grande vulto, que necessitem de empréstimos de longo prazo. Segundo Rezende (1983), no sentido mais restrito a DP implica nas operações de crédito realizadas pelo governo de modo a cobrir déficits de orçamento ou financiar obras e serviços. No sentido mais amplo abarca as operações de crédito referentes às metas da política monetária.

A dívida pública pode ser classificada como sendo de quatro tipos: flutuante, fundada ou consolidada, externa e interna. A dívida flutuante se refere a pequenos montantes resultados de serviços e concordatas que devem ser saldados no prazo máximo de um ano. A dívida consolidada implica em grandes quantias monetárias que receberão como fianças contratos, emissão de títulos e garantias a serem honrados em exercícios futuros. A dívida externa está relacionada a quantias tomadas com credores de outros países. A dívida interna diz respeito aos créditos obtidos junto aos financiadores do próprio país, podendo ser pessoas físicas ou jurídicas (SANDRONI, 2001).

Para a análise da evolução da dívida pública, faz-se necessário a comparação com outras grandezas econômicas. Uma delas é o Produto Interno Bruto (PIB), que constitui um indicador da atividade econômica de um determinado país na medida em que representa o valor total da produção de bens e serviços finais gerado dentro do território de um país (OLIVEIRA, 2002).

O PIB pode ser analisado sob três aspectos: produção, renda e gasto ou consumo. A produção retrata a somatória dos valores líquidos agregados dos campos econômicos primários (produção agrícola, pecuária e extrativista), secundários (indústrias) e terciários (serviços) somado aos impostos e depreciação, e subtraído os incentivos econômicos. A renda diz respeito aos pagamentos de salários, alugueis, lucros, juros, impostos e depreciação, menos os incentivos econômicos. O consumo está relacionado à somatória dos gastos das famílias e do governo, somado aos estoques e exportações, e subtraídas as importações (SANDRONI, 2001).

A dívida pública, assim como todas as ações do governo devem passar pela apreciação pública, pois desde a implantação da Lei de Responsabilidade Fiscal tornou-se evidente a necessidade de transparência das decisões e ações da Administração Pública, sendo que a sociedade passou a ter papel atuante na fiscalização e acompanhamento da destinação dos recursos públicos. Com isso, surgiu a discussão relacionada ao Accountability.

\subsection{Accountability nas Finanças Pública}

A Constituição Federal de 1988, conforme o parágrafo primeiro do artigo 37, estabelece que a administração pública brasileira é obrigada a dar publicidade aos seus atos, garantindo a transparência governamental e possibilitando a participação dos cidadãos. A publicidade dos atos governamentais é elemento indispensável para que os eleitores possam avaliar o desempenho dos governantes, o que se tornou conhecido a partir do conceito de accountability.

O primeiro autor a abordar a temática foi Campos (1990), em seu esforço de conceituar o termo para a língua portuguesa. Pontuou que a dificuldade em encontrar um vocábulo equivalente se deu pelo estágio de desenvolvimento político que o Brasil se encontrava, recém-saído da ditadura militar. Segundo a 
autora, "qualquer tentativa de encontrar uma palavra naquele momento não teria significado, pois seria alheia a realidade vivida no país" (CAMPOS, 1990, p. 17). Neste trabalho, Campos (1990) afirma que accountability seria sinônimo de responsabilidade objetiva, ou seja, a responsabilidade para com outra pessoa ou organização por alguma coisa ou por desempenho de uma tarefa.

Neste mesmo sentido, Nakagawa (1998, p. 17) acrescenta que accountability é "a obrigação de se prestar contas dos resultados obtidos em função das responsabilidades que decorrem de uma delegação de poder". Conforme entendimento de Loureiro e Abrucio (2004), uma tradução possível para accountability seria a palavra responsabilização e significaria um processo institucionalizado de controle político no qual os cidadãos organizados devem participar. Deste modo, são estabelecidas regras a serem seguidas pelo poder político e arenas onde a accountability é exercida.

A essa participação da sociedade O'Donnell (1998) denomina de accountability vertical. Ela se manifesta através de atividades de fiscalização e controle que a sociedade civil exerce sobre governantes e burocratas. Complementarmente, O'Donnell (1998), denomina accountability horizontal quando esta atividade de fiscalização e controle fica a cargo de outros poderes, sem subordinação ao poder que está sendo fiscalizado. Esta forma é conhecida por freios e contrapesos, que consiste no controle e fiscalização mutuamente realizado.

Existem três formas de accountability que garantem a responsabilização do poder público pelos atos praticados: a) a eleição, processo no qual o candidato será avaliado pela sociedade; b) instituições regulatórias do Estado, cuja finalidade é fiscalizar os entes eleitos e os processos burocráticos; c) normas e regras estabelecidas que garantem a manutenção dos direitos do indivíduo e da coletividade (Arantes et al., 2010).

Com a redemocratização do país, os princípios e instrumentos de accountability começaram a ser melhor desenvolvidos, gerando consideráveis impactos no ordenamento das finanças públicas. Este processo teve como resultado a melhoria da qualidade das informações do setor público, que por sua vez garantiu condições para a maior eficiência técnica e controle democrático.

\subsection{A autonomia e responsabilização dos entes federativos}

Além de toda transparência e eficiência alcançadas com o accountability, surgiram também medidas para aumentar a ética no orçamento público (LOUREIRO e ABRUCIO, 2005). Com o advento da Constituição de 1988, ocorreu também a descentralização fiscal, que consistiu no detalhamento das origens das receitas dos estados e garantia de autonomia aos entes federativos para a gestão independente, sendo este um grande avanço na revisão das relações entre instituições do governo (MORA, 2002).

A situação existente até então se pautava em três pilares: 1) o chamado "imposto inflacionário" que geravam receitas extras, tanto pelos reajustes salariais do funcionalismo abaixo do índice de inflação, quanto pelo atraso no pagamento dos credores; 2) contratação de dívidas junto aos bancos estaduais, sem, contudo, efetuar o devido pagamento e, 3) o fato da União sempre renegociar seus créditos com os estados e municípios (LOUREIRO E ABRUCIO, 2004). 
O estado do Mato Grosso era um dos estados brasileiros mais endividados e o indicador da gravidade da crise fiscal enfrentada era o montante da dívida estadual no início de 1995. De acordo com Albano (2001, p.77), a dívida pública do Estado com a União era de aproximadamente $\mathrm{R} \$ 2,9$ bilhões, ou o equivalente a 3,4 vezes a receita própria anual. Em termos de dívida pública, Mato Grosso ocupava o terceiro maior grau de endividamento público.

A partir do Plano Real (1994), com a estabilização dos preços, reduziu-se drasticamente as receitas dos estados com o "imposto inflacionário". Deste modo, ficou evidenciada uma situação quase falimentar nas contas públicas estaduais. Esta fragilidade financeira dos estados em contraste com a maior concentração de poder com a União tornou possível a negociação de um novo modelo de relações intergovernamentais (LOUREIRO E ABRUCIO, 2004). Portanto, o controle da inflação acabou com a possibilidade de os estados permanecerem fazendo uso de artimanhas ilegítimas para equilibrar as despesas e receitas, e mesmo, com o aumento da arrecadação após implantação da nova moeda os estados passaram a registrar déficits primários (MORA, 2002).

Segundo Albano (2001, p.43), o estado de Mato Grosso não aproveitou o período de transição que antecedeu ao Plano Real, quando se adotou a Unidade de Referência de Valor (URV), para ajustar o governo ao novo plano econômico. Ao invés de preparar-se para os impactos restritivos que as mudanças na economia provocariam, concedeu significativo reajuste salarial ao funcionalismo público. A gravidade da situação financeira estadual era evidenciada no desequilíbrio fiscal, que indicava que as despesas superavam as receitas em 41\%, em 1994.

Sob esta nova conjugação de forças, a crise financeira dos estados motivou uma ampla renegociação dessas dívidas que acabaram por ser assumidas pela União, no âmbito da lei 9.496/97. Porém, desta vez com maiores garantias de seu pagamento e incluindo uma série de compromissos assumidos como obtenção de superávit primário, aumento da arrecadação, privatização de empresas públicas, em especial dos bancos estaduais (LOUREIRO $\mathrm{E}$ ABRUCIO, 2004). Assim, uma das maneiras de promover o ajuste fiscal no setor público foi a venda das distribuidoras de energia elétrica e venda e/ou liquidação dos bancos estaduais (MORA E GIAMBIAGI, 2007).

Em Mato Grosso, entretanto, dentre todas as organizações públicas estaduais, somente foi possível a privatização da companhia energética (CEMAT). As demais encontravam-se em situação financeira extremamente precária que não atraíram interessados e acabaram extintas ou liquidadas (ALBANO, 2001, p.33).

Completando as mudanças institucionais do governo de Fernando Henrique Cardoso, no que tange as finanças públicas, foi aprovada a Lei de Responsabilidade Fiscal (LRF). Segundo Mora e Giambiagi (2007, p. 479), "a LRF pode ser considerada um desdobramento do Programa de Reestruturação Fiscal e Financeira, e ainda que tenham sido sobrepostos, ambos, são em linhas gerais complementares". Contudo, três fatores foram fundamentais para que sua aprovação fosse possível: a) o fortalecimento da União frente aos governos estaduais; b) os sucessivos escândalos envolvendo recursos públicos fizeram com que a cultura de responsabilidade fiscal se instalasse na opinião pública e nos atores políticos; e c) a pressão externa exercida pelo Fundo Monetário Internacional (FMI), fiador de um empréstimo de 40 bilhões de dólares para 
socorrer o país depois da grande desvalorização monetária no início de 1999 (LOUREIRO; ABRUCIO, 2004).

\subsection{Lei de Responsabilidade Fiscal (LRF)}

A Lei de Responsabilidade Fiscal (LRF), Lei Complementar 101/2000, implementada em de 4 de maio de 2000, estabeleceu normas de finanças públicas visando à gestão fiscal responsável, buscando garantir o equilíbrio das contas públicas, através do estabelecimento de metas a serem atingidas e limites relacionados a despesas e endividamentos. A LRF no parágrafo primeiro, do artigo primeiro dispõe que é de responsabilidade do gestor o cumprimento de metas de resultados e dos limites quanto à "renúncia de receita, geração de despesas com pessoal, seguridade social, dívidas consolidada e mobiliária, operações de crédito, incluindo antecipação de receita, concessão de garantia e Restos a Pagar" (BRASIL, 2000).

A base de cálculo para os limites estabelecidos nesta lei é a Receita Corrente Líquida (RCL) que no artigo dois, inciso IV é: somatório das receitas tributárias, de contribuições, patrimoniais, industriais, agropecuárias, de serviços, transferências correntes e outras receitas também correntes. No caso dos estados, serão deduzidos os valores entregues aos Municípios por determinação constitucional. A receita corrente líquida será apurada somandose as receitas arrecadadas no mês em referência e nos onze anteriores, excluídas as duplicidades.

Na importante tarefa de determinar os limites de endividamento, renúncia de receita e geração de despesa, a Lei de Responsabilidade Fiscal foi além, e inovou quando apontou caminhos para a uma gestão econômico-financeira responsável e saudável, de modo a corrigir as distorções e desvios antes ocorridos. Portanto, mais do que o estabelecimento de padrões e medidas, a lei se ocupou em prescrever princípios a serem adotados para o atingimento das metas (SANTOS, 2005), cumprindo um importante papel na gestão pública.

O artigo 19 da LRF dispõe que o total da despesa com pessoal nos estados não poderá exceder a $60 \%$ da RCL. Caso este limite seja superado, 0 artigo 23 estabelece o prazo de dois quadrimestres para o ajuste, sendo que pelo menos um terço do excedente deve ser eliminado no primeiro. Para promover 0 ajuste iniciando pela da redução de $20 \%$ com cargos de confiança, depois exonerando servidores não estáveis e por fim pela exoneração dos servidores estáveis.

Do mesmo modo, quando o ente federativo apresenta seu endividamento fora dos parâmetros estabelecidos, obrigatoriamente deverá estabelecer um resultado primário suficiente para se enquadre aos limites constante na lei. Segundo a lei 9496/97 em seu artigo segundo, inciso II, o resultado primário é entendido como o valor reservado para o pagamento da dívida pública, sendo o resultado da diferença entre as receitas primárias e despesas primárias não financeiras, ou seja, as receitas e despesas desconsiderando as despesas e receitas financeiras.

A LRF (artigo 30) imputou ao Senado Federal a incumbência de estabelecer os limites de endividamento dos estados e municípios. Por intermédio da Resolução no 40 de 2001, o Senado estipulou que a partir de 2016 as dívidas consolidadas não poderão exceder a $200 \%$ da RCL dos estados. Se 
a dívida consolidada ultrapassar os limites do Senado, o estado terá três quadrimestres para reconduzi-la aos limites, sendo que deverá reduzir em pelo menos $25 \%$ já no primeiro quadrimestre (Brasil 2000, art. 31).

Outra importante restrição ao endividamento público consta no artigo 35, onde ficou vedada a contração de operações de crédito destinadas ao pagamento de dívidas anteriores ou referentes a despesas correntes. Esta ficou conhecida como a regra de ouro da LRF, pois forçou o combate ao déficit público e a rolagem da dívida. A rolagem implica em incremento da dívida, pois significa que haverá apropriação de juros ao principal.

Conforme sintetiza Loureiro e Abrucio (2005, p. 94), a LRF possui uma série de objetivos, tais como: estabelecer o limite tolerável para a dívida pública e para os gastos públicos, evitar déficits frequentes e além dos limites permitidos, estimular a gestão pública orçamentária responsável, proporcionar a transparência e prestação de contas à sociedade, de modo que esta possa ter acesso às informações e acompanhar a racionalidade no uso dos recursos públicos.

As penalidades decorrentes do descumprimento da LRF poderão acarretar em sanções institucionais tais como retenção de transferências constitucionais e a proibição de contratação de empréstimos e convênios com o Governo Federal. O agente público ainda estará sujeito a sanções pessoais previstas no código penal como cassação de mandato, inabilitação para exercer função pública, multa e detenção, que poderá variar entre 6 meses e 4 anos (NASCIMENTO e DEBUS, 2001), além de outras penas cíveis e criminais.

\subsection{Retrospectiva histórica do Estado de Mato Grosso}

Desde a colonização do estado, no século XVI, inicialmente pelos espanhóis, que não foram tão bem-sucedidos até a chegada dos bandeirantes, no século XVIII, a base econômica do estado de Mato Grosso foi marcada pelo extrativismo mineral e efemeridade (BORGES, 1991). Apesar de existir outras atividades econômicas como cultivo da cana-de-açúcar, pecuária extensiva e agricultura de subsistência, a extração de ouro disputava espaço e por vezes realocava a força de trabalho, por se mostrar mais atrativa (PEREIRA, 2007). Essas atividades tinham uma função complementar à atividade mineradora $\mathrm{e}$ nenhuma delas alcançou volume de produção capaz de gerar excedentes para exportação. Sendo assim, o principal produto exportado no período colonial foi o ouro e ocasionalmente o diamante (PEREIRA, 1995).

Com o esgotamento da atividade mineradora durante o Século XIX, a economia da região direcionou-se para o extrativismo vegetal e para a pecuária extensiva. Além da exploração do diamante, a extração da poaia ${ }^{3}$, da borracha e da erva-mate foram importantes itens na pauta produtiva do Estado. Apesar de receber ampla contribuição desses itens, a economia do estado, no século XIX, esteve fortemente representada pela pecuária extensiva. Com o esgotamento da mineração do ouro, o gado passou a ocupar o posto de principal item de exportação. No início do Século $X X$, a atividade pecuária intensificou sua expansão na parte sul de Mato Grosso (atual estado do Mato Grosso do Sul),

\footnotetext{
${ }^{3}$ Poaia - Cephaelis Ipecacuanha - chamada popularmente de Poaia, planta rampante que cresce na sombra de matas úmidas e sua raíz é utilizada para fazer chá e remédios, essa já foi uma planta abundante no Mato Grosso.
}

Revista de Estudos Sociais | Ano 2017, N. 39, V. 20, Pag. 96 
induzida pela proximidade geográfica com 0 Estado de São Paulo que apresentava forte dinamismo econômico (PEREIRA, 2007).

A construção da ferrovia Ferro Noroeste do Brasil, que interligou BauruSP a Corumbá-MS exerceu impacto transformador e acentuou as diferenças regionais do estado (GUIMARÃES; LEME, 1997). A economia da região Norte, baseada na exploração da borracha, na pecuária extensiva e em algumas esparsas explorações minerais, ficou à margem da integração que a parte sul desfrutou. Em meados do Século XX, ocorreu significativo aumento da produção de bens alimentícios na região Norte. Porém, essa expansão se deu com o emprego de técnicas rudimentares, o que propiciou apenas ganho quantitativo, obtido pela ampliação das áreas exploradas. Inversamente, na região Sul, o emprego de tecnologias intensivas em capital, modernizou a produção agropecuária. Nesse período foi introduzida a produção de soja na região (PEREIRA, 2007).

No âmbito do Plano de Metas ${ }^{4}$ do Governo Federal foram definidas diretrizes com a intenção de promover a expansão da fronteira agrícola nacional, para isso houve significativos investimentos estatais priorizando o transporte rodoviário. O mais importante deles para economia mato-grossense foi a construção da BR 364 que ligou o Sudeste, Centro-Oeste ao Norte do Brasil, seguido pela construção da BR 163, que ligou a Amazônia ao Sul e Sudeste do país e, por fim, a rodovia BR 070, que liga Brasília e Goiânia-Barra ao Mato Grosso. Porém, enquanto a porção Sul mantinha acentuada complementaridade com a economia paulista, a região Norte, mais pulverizada, sofria a interferência de polos menos dinâmicos e complementares à economia de São Paulo, como, por exemplo, Goiânia (PEREIRA, 2007).

Nesse processo transformação da economia mato-grossense, o Governo Federal instituiu uma série de programas com o intuito de incentivar a integração econômica da região no cenário nacional, tais como: Programa de Integração Nacional (PIN), Programa de Redistribuição de Terras e de Estímulo a Agroindústria do Norte e Nordeste (PROTERRA), Programa de Desenvolvimento dos Cerrados (POLOCENTRO). Este último, através do desenvolvimento da pesquisa agropecuária, por meio da Empresa Brasileira de Pesquisa Agropecuária (EMBRAPA), gerou ganhos substanciais de produtividade no cerrado, tanto na área de culturas alimentícias, como na de formação de pastagens (PEREIRA, 1995).

Uma característica comum a esses planos foi a utilização da política de incentivos fiscais para as empresas que investissem em setores considerados prioritários pelo Governo. A aplicação de incentivos fiscais, isenções de impostos e o crédito subsidiado permitiram a expansão produção de bens agrícolas, principalmente aqueles destinados à exportação. No entanto, essa política serviu basicamente às grandes e médias empresas agrícolas, marginalizando os pequenos produtores. Como consequência corroborou para concentração fundiária, uma vez que sem estímulos, as propriedades familiares acabaram sendo incorporadas às empresas agropecuárias (PEREIRA, 1995).

O dinamismo da economia de Mato Grosso atualmente se deve à modernização da agricultura, propiciada pelas políticas estatais que inseriram o cerrado na economia nacional. As modernas técnicas de correção e adubação dos solos, a seleção de variedades de grãos e de pastagens permitiram a

\footnotetext{
${ }^{4}$ Denominação do plano nacional de desenvolvimento do Governo Federal relativo ao quinquênio 1956 61 (Governo Juscelino Kubitschek).
}

Revista de Estudos Sociais | Ano 2017, N. 39, V. 20, Pag. 97 
inserção de novos sistemas de cultivo em áreas antes não aproveitadas ou subaproveitadas. A produção intensiva de soja é o principal resultado observado desse processo, ela e seus derivados se tornaram os principais bens exportados pelo Estado, responsáveis pela geração de importantes divisas externas para o País. Hoje, a sua cadeia produtiva, dita o ritmo do crescimento econômico de Mato Grosso.

\section{PROCEDIMENTOS METODOLÓGICOS}

A forma de abordagem do presente estudo foi quantitativa utilizada nas pesquisas que buscam a relação causa-efeito e para analisar a interação entre variáveis (PRODANOV; FREITAS, 2013). Quanto aos objetivos se trata de pesquisa exploratória, pois visa um aprofundamento na questão da avaliação da dívida e sua sustentabilidade ao longo do tempo.

Os procedimentos metodológicos consistiram de pesquisa bibliográfica e documental. A pesquisa bibliográfica faz uso da contribuição de vários autores em torno de um tema, enquanto a pesquisa documental levanta fontes que ainda não receberam tratamento analítico, podendo ser reformulados em torno do propósito da pesquisa (Gil, 2002). A pesquisa documental foi realizada nos documentos públicos disponibilizados no sítio da Secretaria de Estado de Fazenda de Mato Grosso - SEFAZ-MT e no sítio do Instituto Brasileiro de Geografia e Estatística - IBGE.

\subsection{Método de avaliação da sustentabilidade da dívida pública}

Após a coleta dos dados, estes foram organizados em planilhas eletrônicas para possibilitar a análise por meio de gráficos e tabelas numéricas, de modo a possibilitar a verificação da evolução da dívida pública e assim compará-la a outras grandezas econômicas como Receita Pública e Produto Interno Bruto (PIB). A análise quanto à sustentabilidade da dívida pública utilizou o modelo desenvolvido por Pasinetti (1998).

Para se inferir sobre a sustentabilidade de uma dívida pública, a simples razão dívida/PIB é insuficiente para determinar se o endividamento é sustentável ao longo do tempo, haja vista, que existe outros fatores que interferem no comportamento da dívida ao longo do tempo como: a) a taxa de juros aplicada sobre o montante da dívida, b) a taxa de crescimento do país, e c) o resultado primário obtido. Essas medidas econômicas são contempladas no modelo de Luigi Pasinetti (1998). Neste modelo, o autor considera que o ponto crucial não é o nível alcançado pela relação dívida/PIB e sim sua trajetória ao longo do tempo.

Portanto, uma dívida pública sustentável, segundo Pasinetti (1998) deve satisfazer a seguinte condição:

$$
\left(\frac{D}{Y}\right)_{(t)} \leq\left(\frac{D}{Y}\right)_{(0)}
$$

D > 0: dívida pública;

Y: Produto Interno Bruto (PIB), em termos nominais ;

t: tempo. 
Significa portanto que a dívida pública é definada como sustentável quando a proporção $\mathrm{D} / \mathrm{Y}$ diminui ou permanece constante no periodo. Caso contrário, é considerada insustentável, quando aumenta na mesma comparação. Considerando que:

$$
\frac{\mathrm{q}}{\mathrm{g}} \frac{\mathrm{D}}{\mathrm{Y}} \leq \frac{\mathrm{D}}{\mathrm{Y}}, \quad \text { i. e. }: \mathrm{q} \leq \mathrm{g}
$$

Onde,

$q=\frac{\Delta D}{D}:$ é a taxa anual de crescimento da dívida pública.

$\mathrm{g}=$ taxa anual do crescimento nominal do PIB.

Adicionando agora as seguintes definições (todas em termos nominais):

$\mathrm{R}>0$ : receita pública total anual;

G> 0: despesa líquida pública anual;

$\mathrm{S}^{(\mathrm{p})}=\mathrm{R}-\mathrm{G}$ : resultado primário anual (superávit ou déficit);

$S=-\Delta \mathrm{D}$ : resultado nominal público anual (superávit ou déficit);

i: taxa de juros nominal anual;

Então, podem ser formuladas as seguintes identidades orçamentárias: o resultado nominal $(S)$ e o resultado primário $\left(S^{(p)}\right)$; expressos em valores nominais absolutos e em relação ao PIB.

$$
\begin{aligned}
& S=-\Delta D=R-G-i D, \\
& S^{(p)}=R-G=S+i D=-\Delta D+i D, \\
& \frac{S}{Y}=-\frac{(\Delta D)}{D} \frac{D}{Y}=-q \frac{D}{Y}=\frac{S^{(p)}}{Y}-i \frac{D}{Y}, \\
& \frac{S^{(p)}}{Y}=\frac{S}{Y}+i \frac{D}{Y}=-q \frac{D}{Y}+i \frac{D}{Y}
\end{aligned}
$$

Simplificando temos que:

$$
\frac{S^{(p)}}{Y}=(i-q) \frac{D}{Y}
$$

Assim, a área de sustentabilidade da dívida pública pode ser definida com referência ao resultado primário:

$$
\frac{S^{(p)}}{Y} \geq(i-g) \frac{D}{Y}
$$


A equação demonstra que a sustentabilidade da dívida pública é alcançada quando o superávit primário gerado em relação ao PIB pelo governo (lado esquerdo da equação) é maior ou igual a relação dívida pública/PIB multiplicado pela diferença a taxa de juros nominal e a taxa de crescimento nominal do PIB (lado direito da equação).

\section{DESCRIÇÃO E ANÁLISE DOS DADOS}

Para a análise da Dívida Pública do estado de Mato Grosso, levantaramse os dados referentes aos valores da Dívida Pública Consolidada, valores do Produto Interno Bruto (PIB) e a relação comparativa entre dívida pública e PIB, no período de 2002 a 2012. Após análise por meio de estatística descritiva às variações dos valores referentes a Dívida Pública, ao Produto Interno Bruto e do Resultado Primário e das relações estabelecidas entre estes valores, empregouse a ferramenta de análise para verificação quanto à sustentabilidade da dívida. Para tanto, foi aplicado o modelo de Pasinetti (1998), considerando a taxa de juros (i) a partir da base estabelecida na Lei 9496/97, que tratou da reestruturação das dívidas dos estados. $O$ artigo $3^{\circ}$ da referida lei estabelece que o montante da dívida será corrigido monetariamente com base na variação do Índice Geral de Preços - Disponibilidade Interna (IGP-DI) mais juros de seis por cento ao ano.

Os dados referentes à Dívida Pública de Mato Grosso estão dispostos na Tabela 1, que apresenta os valores da Dívida Pública Consolidada, do Produto Interno Bruto (PIB) e a relação dívida pública comparada ao PIB.

Tabela 1 - Relação Dívida Pública Consolidada e Produto Interno Bruto do Estado de Mato Grosso - 2002 a 2012

\begin{tabular}{cccc}
\hline \multicolumn{2}{c}{ Valores em milhões de reais } \\
Anos & $\begin{array}{c}\text { Dívida } \\
\text { Pública Consolidada }\end{array}$ & $\begin{array}{c}\text { PIB a preços de } \\
\text { mercado }\end{array}$ & $\begin{array}{c}\text { Consida Pública } \\
\text { Consolidada/PIB }\end{array}$ \\
\hline 2002 & 6.084 & 20.941 & $29,05 \%$ \\
2003 & 5.942 & 27.889 & $21,31 \%$ \\
2004 & 6.044 & 36.961 & $16,35 \%$ \\
2005 & 5.786 & 37.466 & $15,44 \%$ \\
2006 & 5.593 & 35.258 & $15,86 \%$ \\
2007 & 5.356 & 42.687 & $12,55 \%$ \\
2008 & 5.389 & 53.386 & $10,09 \%$ \\
2009 & 4.804 & 57.294 & $8,39 \%$ \\
2010 & 4.913 & 59.600 & $8,24 \%$ \\
2011 & 4.621 & 71.418 & $6,47 \%$ \\
2012 & 4.536 & 80.830 & $5,61 \%$
\end{tabular}

Fonte: SEFAZ/MT (2014) e IBGE (2014).

* Valores da Dívida Pública Consolidada: Relatório Resumido da Execução Orçamentária - RREO (LRF) - Anexo VI - Demonstrativo do Resultado Nominal (SEFAZ/MT, 2014).

$\mathrm{Na}$ análise da tabela 1, percebe-se um declínio do montante da dívida pública, que somava $R \$ 6.054$ milhões de reais em 2002 para $R \$ 4.536$ milhões em 2012, representando uma redução no valor nominal de $25,4 \%$ no período. $O$ 
PIB no mesmo período apresenta um forte crescimento passando de $R \$ 20.941$ milhões em 2002 para $R \$ 80.830$ milhões em 2012, ou seja, um crescimento nominal de 286\%. À exceção do ano 2006, ano de forte crise no agronegócio, todos os anos apresentaram crescimento nominal no PIB. O comportamento destas duas variáveis se refletiu na relação Dívida Pública/PIB que declinou acentuadamente no período pesquisado, partindo de 29,05\% em 2002 para $5,61 \%$ em 2012, significando 23,4 pontos percentuais a menos.

A relação gráfica entre Dívida Pública Consolidada e PIB pode ser visualizada na Figura 1.

Figura 1 - Gráfico da relação Dívida Pública e PIB Fonte: SEFAZ/MT (2014) e IBGE (2014).

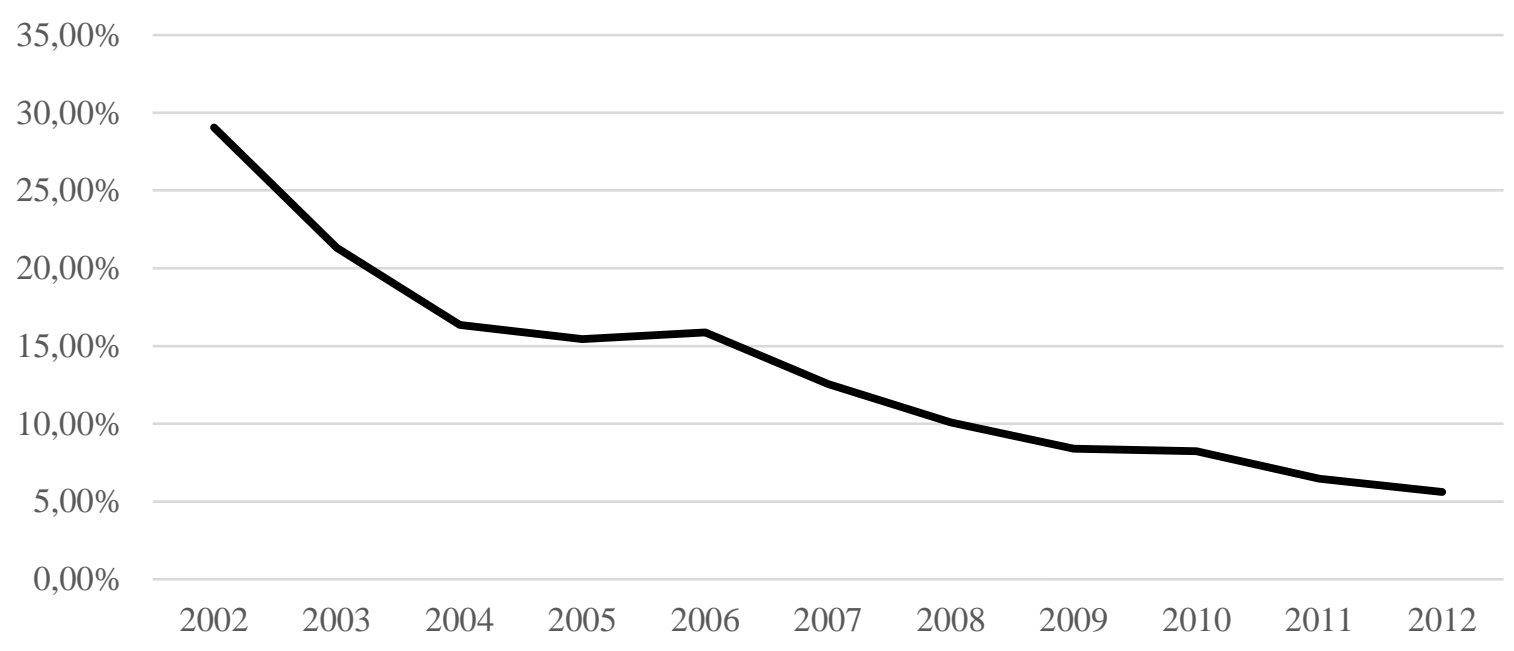

Graficamente é possível verificar o comportamento tendendo ao declínio da dívida pública mato-grossense com o decorrer dos anos. Essa relação foi possível tanto pelo crescimento do PIB quanto pelo esforço para manter a dívida controlada e em perspectiva descendente, indicando que o governo do estado estava empenhado em cumprir os preceitos da Lei de Responsabilidade Fiscal e tornar a gestão do estado mais eficiente e responsável.

Quanto ao crescimento do PIB, segundo o IBGE (2017), no período de 2012 e 2014, Mato Grosso foi o segundo estado brasileiro com maior taxa de crescimento (105,6\% e média de $6,2 \%$ ao ano), ficando atrás apenas de Tocantins (113\%). Mato Grosso também respondeu pelo maior PIB per capita da região Centro-Oeste nesse período, excluindo-se o Distrito Federal, que é um caso especial e não pode ser avaliado com a mesma perspectiva econômica que as outras unidades da federação. O crescimento expressivo do PIB do estado no período ocorreu devido ao bom momento da agropecuária, principalmente pela elevação da produção de soja. Outros fatores que contribuíram para o aumento foram a expansão do comércio e da indústria de transformação (Mildenberger, 2013).

As análises seguintes foram referentes à relação entre dois importantes indicadores, sendo o Resultado Primário e o Produto Interno Bruto, todos apresentados na Tabela 2. 
Tabela 2 - Relação Resultado Primário e Produto Interno Bruto do Estado de Mato Grosso - 2002 a 2012

\begin{tabular}{cccc}
\hline Anos & \multicolumn{2}{c}{ Valores em milhões de reais } & $\begin{array}{c}\% \text { Resultado } \\
\text { PIB a preços de } \\
\text { mercado }\end{array}$ \\
\hline 2002 & 409 & 20.941 & $1,95 \%$ \\
2003 & 413 & 27.889 & $1,48 \%$ \\
2004 & 554 & 36.961 & $1,50 \%$ \\
2005 & 606 & 37.466 & $1,62 \%$ \\
2006 & 527 & 35.258 & $1,49 \%$ \\
2007 & 544 & 42.687 & $1,27 \%$ \\
2008 & 786 & 53.386 & $1,47 \%$ \\
2009 & 120 & 57.294 & $0,21 \%$ \\
2010 & 721 & 59.600 & $1,21 \%$ \\
2011 & 770 & 71.418 & $1,08 \%$ \\
2012 & 699 & 80.830 & $0,86 \%$ \\
\hline
\end{tabular}

Fonte: SEFAZ/MT (2014) e IBGE (2014).

* Valores do Resultado Primário: Relatório Resumido da Execução Orçamentária RREO (LRF) - Anexo VII - Demonstrativo do Resultado Primário (SEFAZ/MT, 2014).

O resultado primário de Mato Grosso no período de 2002 a 2012 apresentou performance positiva, progredindo de $\mathrm{R} \$ 409$ para $\mathrm{R} \$ 699$ milhões, significando uma variação nominal de $71 \%$. No entanto, quando se estabelece a relação com o PIB, percebe-se que houve uma redução de 1,09 pontos percentuais. Em 2002, o resultado primário representou 1,95\% do PIB e em 2012 esse valor foi alterado para $0,86 \%$, ou seja, reduziu-se em $55,71 \%$ no período. $\mathrm{Na}$ Figura 2 é possível visualizar com facilidade a trajetória da relação Resultado Primário/PIB.

Figura 2 - Gráfico da relação Superávit Primário e PIB

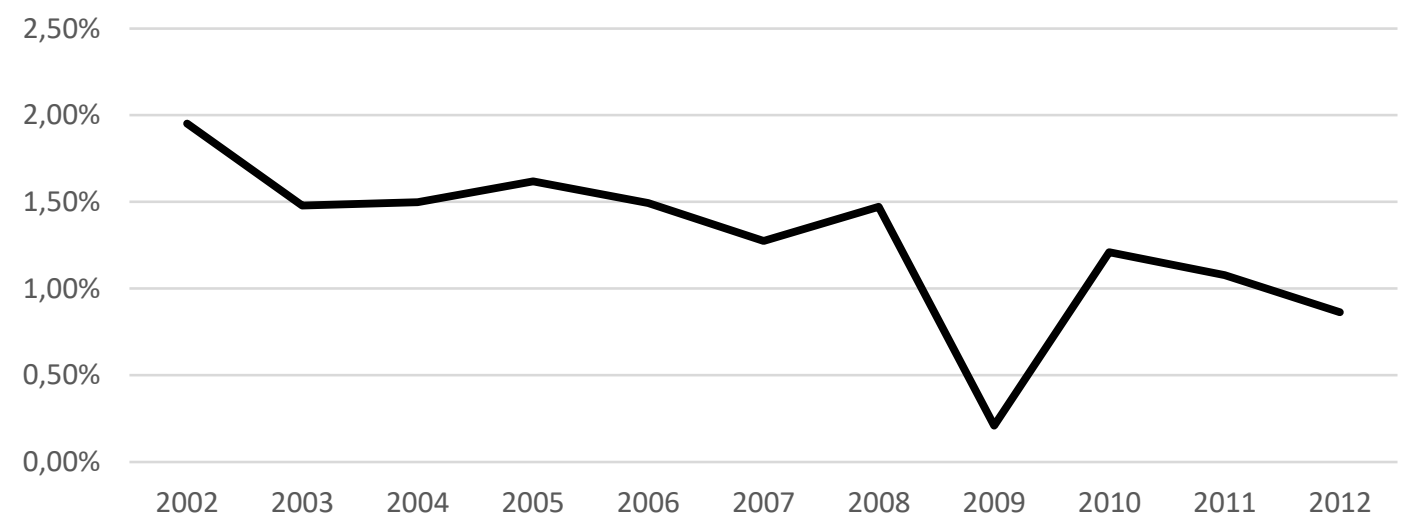

Fonte: SEFAZ/MT (2014) e IBGE (2014).

Nota-se uma queda brusca no Resultado Primário para o ano de 2009. Esse fato ocorreu devido a duas razões: a primeira foi a liberação de crédito pelo superávit financeiro e a segunda foi a decisão de investimentos com créditos abertos para aquisição de máquinas, equipamentos pesados e caminhões para 
o Programa MT 100\% Equipado (SEFAZ/MT, 2009). É importante ressaltar que no Relatório Resumido da Execução Orçamentária (SEFAZ/MT, 2014), o valor apresentado foi de $\mathrm{R} \$ 120$ milhões, no entanto no Relatório Circunstanciado (SEFAZ/MT, 2009) foi feito um ajuste com a justificativa de que os fenômenos acima descritos alteraram o "resultado real" do período. Contudo, sendo esse estudo baseado na Lei de Responsabilidade Fiscal, o valor considerado foi o do Relatório Resumido da Execução Orçamentária, por representar a realidade das decisões governamentais pertinentes ao exercício.

Prosseguindo com as análises para o mesmo período, a Tabela 3 especifica a Receita Corrente Líquida do Estado e estabelece a relação com o Resultado Primário.

Tabela 3 - Relação Resultado Primário e Receita Corrente Líquida do Estado de Mato Grosso - 2002 a 2012

\begin{tabular}{cccc}
\hline & \multicolumn{2}{c}{ Valores em milhões de reais } & Receita \\
Anos & & $\begin{array}{c}\text { Resultado Primário } \\
\text { /RCL }\end{array}$ \\
& Resultado Primário & Corrente Líquida (RCL) & $16,27 \%$ \\
2002 & 409 & 2.513 & $13,16 \%$ \\
2004 & 413 & 3.136 & $14,30 \%$ \\
2005 & 554 & 3.873 & $14,12 \%$ \\
2006 & 606 & 4.296 & $11,66 \%$ \\
2007 & 527 & 4.517 & $11,15 \%$ \\
2008 & 544 & 4.882 & $12,71 \%$ \\
2009 & 786 & 6.182 & $1,86 \%$ \\
2010 & 120 & 6.468 & $10,16 \%$ \\
2011 & 721 & 7.100 & $9,84 \%$ \\
2012 & 770 & 7.820 & $7,85 \%$ \\
\hline Fonte: SEFAZ/MT (2014). & 699 & 8.900 & \\
* Valores do Resultado Primário: Relatório Resumido da Execução Orçamentária - Anexo III \\
** Valores da RCL: Demonstrativo da Receita Corrente Líquida - Anexo VII
\end{tabular}

A Receita Corrente Líquida apresentou um forte incremento no período, partindo de $R \$ 2.513$ milhões em 2002 para $R \$ 8.900$ milhões em 2012, cuja variação nominal correspondeu a $254 \%$ no período. O resultado primário, quando comparado a RCL, da mesma forma como foi comparado ao PIB, também apresentou recuo na ordem de 8,42 pontos percentuais. No início do período significava $16,27 \%$ da $\mathrm{RCL}$ e em 2012 passou para $7,85 \%$, ou 0 equivalente a $51,73 \%$ a menos no período.

Na mesma sequência, a Tabela 4 apresenta a relação Dívida Pública Consolidada e Receita Corrente Líquida.

A tabela 4 apresenta a comparação entre Dívida Pública e Receita Corrente Líquida. No período a relação Dívida Pública/RCL recuou de 242,1\% em 2002 para 50,97\% em 2012, equivalente a 191,13 pontos percentual a menos. Em termos relativos, a relação Dívida Pública/RCL de 2012 representa $21,05 \%$ da mesma relação de 2002. 
Tabela 4 - Relação Dívida e Receita Corrente Líquida do Estado de Mato Grosso - 2002 a 2012

\begin{tabular}{cccc}
\hline \multicolumn{4}{c}{ Valores em milhões de reais } \\
Anos \\
& $\begin{array}{c}\text { Dívida } \\
\text { Pública Consolidada }\end{array}$ & $\begin{array}{c}\text { Receita Corrente } \\
\text { Líquida (RCL) }\end{array}$ & $\begin{array}{c}\text { \%ública / RCL } \\
\text { Rida }\end{array}$ \\
\hline 2002 & 6.084 & 2.513 & $242,10 \%$ \\
2003 & 5.942 & 3.136 & $189,45 \%$ \\
2004 & 6.044 & 3.873 & $156,06 \%$ \\
2005 & 5.786 & 4.296 & $134,68 \%$ \\
2006 & 5.593 & 4.517 & $123,82 \%$ \\
2007 & 5.356 & 4.882 & $109,71 \%$ \\
2008 & 5.389 & 6.182 & $87,17 \%$ \\
2009 & 4.804 & 6.468 & $74,27 \%$ \\
2010 & 4.913 & 7.100 & $69,20 \%$ \\
2011 & 4.621 & 7.820 & $59,09 \%$ \\
2012 & 4.536 & 8.900 & $50,97 \%$ \\
\hline
\end{tabular}

Fonte: SEFAZ/MT (2014).

A relação Dívida Pública/RCL de 2012 para 2002 sofreu redução de $78,95 \%$ no período. Verifica-se que esta relação em 2012 se encontra bem abaixo do limite estipulado pela resolução do senado (Resolução 40/2001) que determina que a dívida pública não pode exceder em $200 \%$ a receita corrente líquida, ao final de 2016.

Figura 3 - Gráfico da relação Dívida Pública e RCL

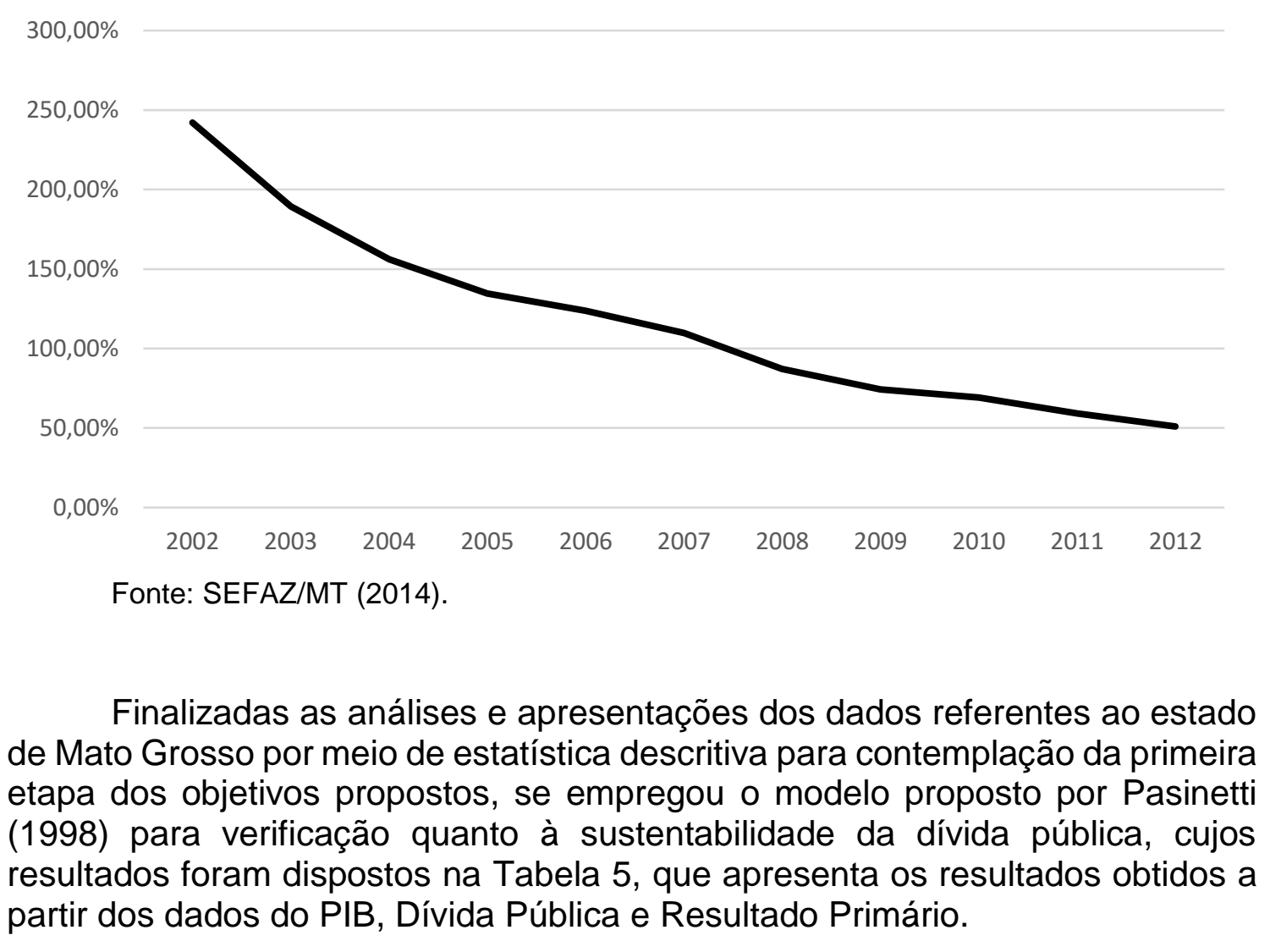

Revista de Estudos Sociais | Ano 2017, N. 39, V. 20, Pag. 104 
Tabela 5 - Sustentabilidade da Dívida Pública do Estado de Mato Grosso - 2002 a 2012

\begin{tabular}{crrr}
\hline Anos & $\begin{array}{c}\text { S(p)/Y (Superávit } \\
\text { Realizado) }\end{array}$ & $\begin{array}{c}\text { i-g (D/Y) } \\
\text { (Superávit } \\
\text { Necessário) }\end{array}$ & $\begin{array}{l}\text { Sustentável (+) / } \\
\text { Insustentável (-) }\end{array}$ \\
\hline 2002 & 1,95 & 1,17 & 0,79 \\
2003 & 1,48 & $-4,16$ & 5,64 \\
2004 & 1,50 & $-2,35$ & 3,85 \\
2005 & 1,62 & 0,90 & 0,71 \\
2006 & 1,49 & 2,49 & $-0,99$ \\
2007 & 1,27 & $-0,90$ & 2,18 \\
2008 & 1,47 & $-1,01$ & 2,48 \\
2009 & 0,21 & $-0,23$ & 0,44 \\
2010 & 1,21 & 1,09 & 0,12 \\
2011 & 1,08 & $-0,57$ & 1,65 \\
2012 & 0,86 & 0,05 & 0,81 \\
\hline
\end{tabular}

Fonte: SEFAZ/MT (2014) e IBGE (2014).

Na Tabela 5 são apresentados o Superávit Realizado, que é o superávit primário em relação ao $\mathrm{PIB}\left(\mathrm{S}^{(\mathrm{p})} / \mathrm{Y}\right)$ e o Superávit Necessário $(\mathrm{i}-\mathrm{g}(\mathrm{D} / \mathrm{Y}))$, que é a relação dívida pública/PIB multiplicado pela taxa de juros para o período de 2002 a 2012. Quando o Superávit Realizado é igual ou superior ao Superávit Necessário, infere-se que a dívida pública está em uma trajetória sustentável. Analisando esta tabela, verifica-se que foram realizados superávits acima do necessário em 10 anos do período analisado. Apenas em 2006, o superávit realizado não foi suficiente para atender ao critério de sustentabilidade do modelo, pelas razões já expostas, referentes à crise do agronegócio que afetou diretamente a economia do estado, pela alta dependência de Mato Grosso para com este setor econômico. A relação entre Superávit Realizado e Superávit Necessário fica mais nítido na Figura 4.

Figura 4 - Gráfico da sustentabilidade da Dívida Pública - Modelo de Pasinetti (1998)

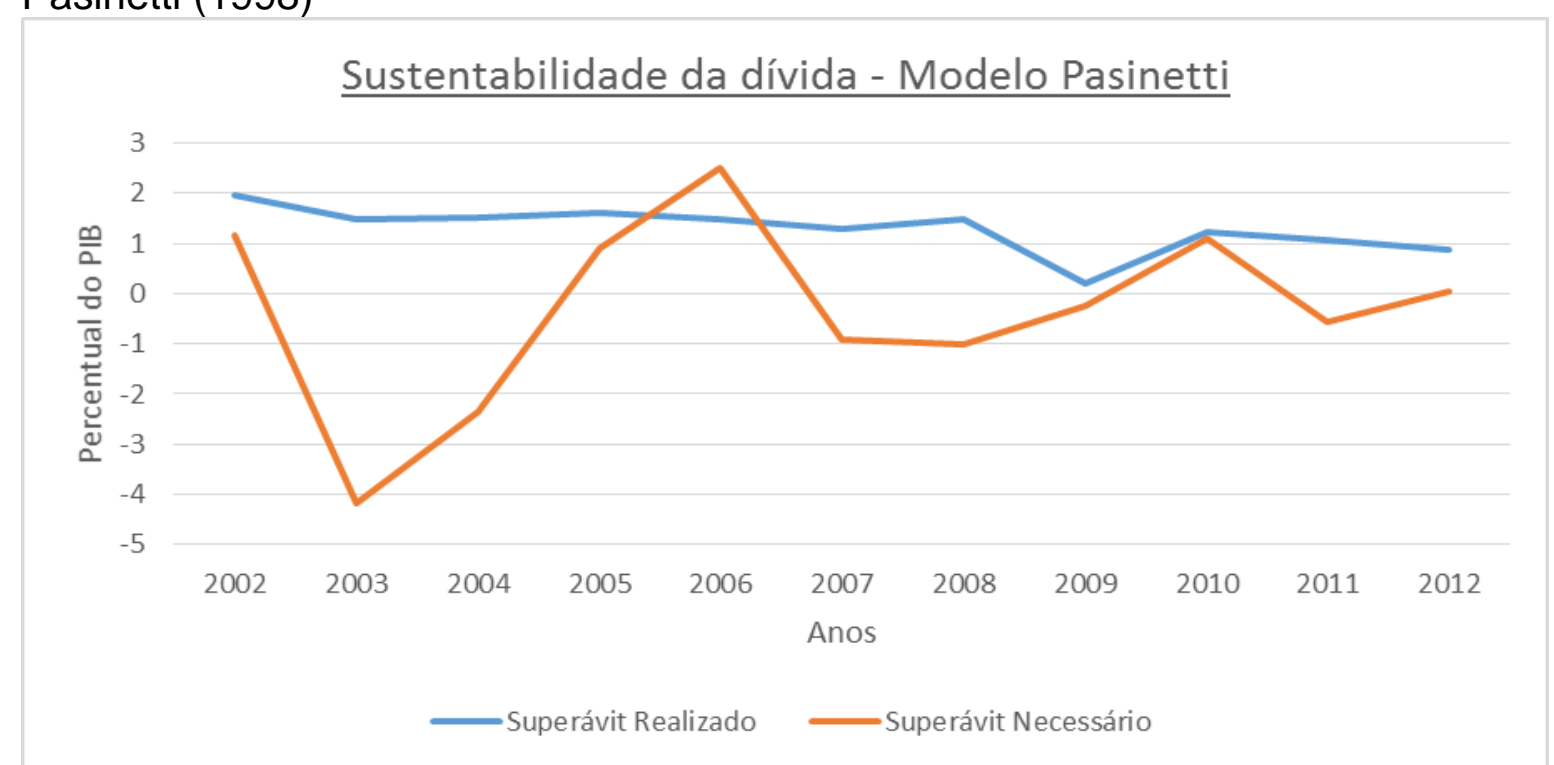

Fonte: SEFAZ/MT (2014); IBGE (2014).

Revista de Estudos Sociais | Ano 2017, N. 39, V. 20, Pag. 105 
Na figura 4 é possível observar que o Superávit Necessário apresentou percentuais negativos em seis anos. O motivo para este fenômeno foi 0 crescimento elevado do Produto Interno Bruto nesse período. Segundo os preceitos do modelo de Pasinetti (1998), quando a taxa anual do crescimento nominal do PIB (g) é maior que taxa de juros nominal anual (i), o multiplicador aplicado sobre a relação Dívida Pública/PIB torna-se negativo. Isso significa dizer que devido à alta taxa de crescimento da economia, mesmo apresentando déficit primário nestes anos, a dívida pública não sairia da trajetória de sustentabilidade.

Essa análise vem ao encontro do que afirma Mora (2002). Segundo o autor, o crescimento da economia é uma condição sem a qual não se pode assegurar a sustentabilidade no longo prazo da dívida pública. Isto ocorre porque, por um lado as receitas públicas apresentam uma forte correlação com - PIB, ou seja, quando a economia cresce, a receita pública tende a crescer proporcionalmente e quando a economia decresce a receita segue no mesmo sentido. Por outro lado, quando ocorre redução do PIB, as despesas públicas são mais inflexíveis à redução em termos absolutos. Portanto, é evidente que se torna muito difícil para a administração pública manter superávits primários elevados em um quadro de recessão econômica.

\section{CONSIDERAÇÕES FINAIS}

Este estudo se propôs a analisar o comportamento da dívida pública do estado de Mato Grosso no período de 2002 a 2012. Considerando que a entrada em vigor da Lei de Responsabilidade Fiscal em 2001 impôs uma série de limitações legais no que se refere ao endividamento público, a hipótese prevista no início do trabalho é que a dívida pública deveria diminuir gradativamente tanto em relação ao Produto Interno Bruto (PIB) quanto em relação à Receita Corrente Líquida (RCL). Para verificação desta suposição, foram levantados os valores referentes a dívida pública, ao Produto Interno Bruto, a Receita Corrente Líquida e ao resultado primário do estado de Mato Grosso para o período de uma década, calculado o percentual da dívida em relação ao PIB e a RCL; e por fim realizada a inferência quanto à sustentabilidade da dívida ao longo do período analisado.

Os principais resultados encontrados atestaram que o endividamento do estado em relação ao PIB declinou acentuadamente no período, por duas razões, o aumento exponencial do PIB, que apresentou crescimento nominal de $286 \%$ e a redução da dívida pública, que diminuiu nominalmente em $25,4 \%$, gerando uma relação dívida pública/PIB com redução de 29,05\% no período analisado. No que se refere ao resultado primário do período, este variou positivamente registrando crescimento nominal de $71 \%$, embora, sua relação com o PIB tenha demonstrado redução de 1,09 pontos percentuais.

A Receita Corrente Líquida, similarmente ao desempenho do PIB, apresentou forte crescimento nominal atingindo $254 \%$ no período. Quanto à relação dívida pública/RCL, houve redução de 242,1\% em 2002 para 50,97\% em 2012. Portanto, constatou-se que esta relação em 2012 se encontrava bem abaixo do limite estipulado pela Resolução 40/2001, que determinava que a dívida pública não poderia exceder em $200 \%$ a receita corrente líquida ao final de 2016. 
Preliminarmente, essa significativa redução indica que a dívida pública está em uma trajetória sustentável. Para confirmação quanto à sustentabilidade, foi aplicado o modelo teórico de Pasinetti. Segundo os resultados da aplicação do modelo, em 10 anos o superávit realizado foi superior ao que seria necessário para a sustentabilidade da dívida e em apenas um ano o superávit foi insuficiente. Este ano em específico, foi marcado por uma forte crise econômica no estado, que resultou em crescimento negativo do PIB.

A trajetória sustentável verificada no período estudado foi confirmada pelo estudo da Firjan (2017), que atestou o índice de endividamento de Mato Grosso em $40 \%$, colocando-o entre os 14 estados com menor nível de endividamento do país, abaixo de $50 \%$. Portanto, observa-se que as limitações legais impostas pela Lei de Responsabilidade Fiscal no que se refere ao endividamento público tem contribuído para a condução da dívida estadual a níveis plenamente administráveis. Cabe destacar que o expressivo crescimento do PIB foi determinante na condução da Dívida Pública aos atuais patamares, pois em paralelo ao crescimento do PIB, as receitas públicas do estado também cresceram.

Se a economia do estado, principalmente a fatia gerada pelo agronegócio conseguir se manter estável, a dívida também estará sobre controle. Porém, a crise econômica acabou por expor a capacidade frágil de liquidez financeira dos estados brasileiros, cujo principal fator apontado foram os gastos com pessoal, em especial os inativos e pensionistas e, nesse quesito, há motivos para 0 governo estadual manter a cautela com as despesas previdenciárias, pois ela continua em trajetória ascendente, de modo que em 2016 foi necessário, 0 aporte da RCL para cobrir as despesas com pessoal, que já extrapolou o limite fixado pela LRF (60\%), chegando a 67,3\% (FIRJAN, 2017).

Dessa forma, foi possível constatar que Mato Grosso está entre os poucos estados brasileiros com índice de endividamento controlado, de modo que não será necessário corte geral de investimentos em infraestrutura e segurança, como vem ocorrendo em outras unidades federativas. Todavia, é recomendada maior atenção previdenciária. As limitações da pesquisa são referentes aos anos pesquisados, não havendo dados disponíveis para os últimos anos. A disponibilização de novos dados, possibilitará a realização de nova inferência quanto à trajetória da dívida pública do estado.

\section{REFERÊNCIAS}

ALBANO, V. Do Caos ao equilíbrio Fiscal, uma difícil travessia. Ed. Entrelinhas, Mato Grosso, 2001.

ARANTES, R.B; LOUREIRO, M.R; COUTO, C; TEIXEIRA, M.A.C. Controles Democráticos, sobre a administração pública no Brasil. In: Burocracia e política no Brasil: desafios para a ordem democrática no século XXI / Orgs. LOUREIRO, M.R; ABRUCIO, F.L; PACHECO, R.S - Rio de Janeiro: Editora FGV, 2010 (p. 109 - 148).

BALEEIRO, A. Uma introdução à ciência das finanças. 14. ed. rev. atual por Flávio Bauer Novelli. Rio de Janeiro: Forense, 1996. 
BANCO CENTRAL DO BRASIL. Finanças Públicas: Sumário dos Planos Brasileiros de Estabilização e Glossário de Instrumentos e Normas Relacionados à Política Econômico-Financeira. 6. ed. Brasília, DF, 2008. Disponível em:<http:// www.bcb.gov.br/?MANFINPUB>. Acesso em: 30 nov. 2014.

BARROS, G. S. de C.; SILVA, S. F. A balança comercial do agronegócio brasileiro de 1989 a 2005. Revista de Economia e Sociologia Rural, v. 46, n. 4, p. 905-935, 2008.

BRASIL, 2000. LEI COMPLEMENTAR № 101, DE 4 DE MAIO DE 2000. Disponível em: <http://www.planalto.gov.br/ccivil_03/leis/LCP/Lcp101.htm>. Acesso em: 23 nov. 2014.

BORGES, F. T. M. Do Extrativismo à Pecuária: Algumas Observações sobre a História Econômica de MT (1870 a 1930). Cuiabá: genus, 1991.

CAMPOS, A. M. Accountability: quando poderemos traduzi-la para o português? Revista de Administração Pública, Rio de Janeiro, fev./abr. 1990.

CHIAVENATO, I. Administração nos novos tempos. 2. ed. Rio de Janeiro: Campus, 1999.

CHIAVENATO, I. Teoria Geral de Administração. 6. ed. Rio de Janeiro: Elsevier, 2001.

DIPIETRO, M. S. Z. Direito Administrativo, São Paulo: Atlas, 1997. 2002.

GIL, A. C. Como elaborar projetos de pesquisa. 4. ed. São Paulo: Atlas,

GUIMARAES, E. N.; LEME, H. J. C. Caracterização Histórica e Configuração Espacial da Estrutura Produtiva do Centro Oeste. Campinas: UNICAMP, Textos NEPO, p. 21-73, dez. 1997.

INSTITUTO BRASILEIRO DE GEOGRAFIA E ESTATÍSTICA. IBGE. Contas Regionais. Disponível em:

<http://www.ibge.gov.br/home/estatistica/economia/contasregionais/2012/defaul t_xls_2002_2012.shtm>. Acesso em: 30 nov. 2014.

Contas Regionais 2014: cinco estados responderam por quase dois terços do PIB do país. Disponível em: $<$ https://censo2010.ibge.gov.br/noticias-

censo. $h$ tml ?view=noticia\&id $=1$ \&idnoticia $=3315$ \&busca $=1 \& \mathrm{t}=$ contas -regionais 2014-cinco-estados-responderam-quase-dois-tercos-pib-pais>. Acesso em: 26 set. 2017.

FEDERAÇÃO DAS INDÚSTRIAS DO ESTADO DO RIO DE JANEIRO. FIRJAN. (FIRJAN, 2017). A Situação Fiscal dos Estados Brasileiros. Disponível em: 
<http://www.firjan.com.br/lumis/portal/file/fileDownload.jsp?fileld=2C908A8A555 B47FF015578AFAE126AA9.>. Acesso em 17 out. 2017.

FUNDO MONETÁRIO INTERNACIONAL. FMI. Brazil. Selected issues. IMF Country Report N. 16/349. November 2016. Disponível em: $<$ https://www.imf.org/external/pubs/ft/scr/2016/cr16349.pdf>. Acesso em 17 out. 2017.

LOUREIRO, M. R.; ABRUCIO, F. L. Política e Reformas Fiscais no Brasil Recente. Revista de Economia Política, São Paulo, volume 24, n.1 (93). Jan/mar 2004.

LOUREIRO, M. R.; ABRUCIO, F.L. Finanças Públicas, Democracia e Accountability. In: Ciro Biderman; Paulo Roberto Arvate. (Org.). Economia do Setor Público no Brasil. Economia do Setor Público no Brasil. 1 ed. Rio de Janeiro: Editora Campus, 2005, v. 1, p. 75-102.

MARCONI, M. A. e LAKATOS, E. M. Técnicas de Pesquisa. 6. Ed. São Paulo: Atlas, 2006.

MATIAS-PEREIRA, J. Curso de Administração Pública: foco nas instituições e ações governamentais. 3. ed. São Paulo: Atlas, 2010.

MILDENBERGER, L. Notícias - Secretaria de Estado de Fazenda de Mato Grosso. 2013. Disponível em: <http://www5.sefaz.mt.gov.br/-/er-3>. Acesso em: 26 set. 2017.

MORA, M. Federalismo e Dívida Estadual no Brasil. Textos para discussão, ํo 866. Rio de Janeiro: Ipea, 2002.

MORA, M.; GIAMBIAGI, F. Federalismo e Endividamento Subnacional: uma discussão sobre a sustentabilidade da dívida estadual. Revista de Economia Política, São Paulo, v. 27, n. 3, jul./set. 2007.

NASCIMENTO, E. R.; DEBUS, I. Entendendo a lei de responsabilidade fiscal. 2a. ed. Brasília: STN, 2001.

NAKAGAWA, M. Introdução a controladoria: conceitos, sistemas, implementação. São Paulo: Atlas, 1998.

O'DONNELL, G. Accountability horizontal e novas poliarquias. Lua Nova, São Paulo, n. 44,p. 27-52, 1998.

OLIVEIRA, G. B. de. Uma discussão sobre o conceito de desenvolvimento. Revista da FAE, v. 5, n. 2, 2002.

PASINETTI, L. The myth (or folly) of the $3 \%$ deficit/ GPD Maastricht 'parameter', 1998. 
PEREIRA, B. D. Industrialização da agricultura de Mato Grosso. Cuiabá: EdUFMT, 1995.

PEREIRA, B. D. Mato Grosso - Principais eixos viários e a modernização da agricultura. Cuiabá: EdUFMT, 2007.

PISCITELLI, R. B. Uma abordagem da administração financeira pública. 11. ed. São Paulo: Atlas, 2010.

PREVIDÊNCIA. Reforma da Previdência. Disponível em <http://www.reformadaprevidencia.gov.br/>. Acesso em: 17 out. 2017.

PRODANOV, C. C. e FREITAS, E. C. Metodologia do trabalho científico: Métodos e Técnicas da Pesquisa e do Trabalho Acadêmico. 2 ed. Novo Hamburgo: Feevale, 2013.

REZENDE, F. Finanças Públicas, São Paulo: Atlas, 1983.

RIANI, F. Economia do setor público: uma abordagem introdutória. 4. ed. São Paulo: Atlas, 2002.

SANDRONI, P. Novíssimo dicionário de economia. 6. ed. São Paulo: Best Seller, 2001.

SANTOS, L. C. Lei de Responsabilidade Fiscal: transparência e responsabilidade. In: Matta, Alfredo Eurico Rodrigues et al. (Org.). Educação, Cultura e Direito: coletânea em homenagem. Salvador: Editora da Universidade Federal da Bahia - EDUFBA, 2005, v. 01, p. 818-822.

SECRETARIA DE ESTADO DE FAZENDA. MATO GROSSO. SEFAZMT. Relatório Resumido da Execução Orçamentária. Disponível em: <http://www.sefaz.mt.gov.br/portal/Financeiro/ContGovernamental/RelLeiRespo nFiscal.php>. Acesso em: 30 nov. 2014. Disponível
$\begin{gathered}\text { Relatório Circunstanciado sobre as contas - } 2009 . \\ \text { em: }\end{gathered}$
https://www.sefaz.mt.gov.br/portal/Financeiro/ContGovernamental/BalancoGera l/2009/01_V_I_Relatorio_Circunstanciado.pdf >. Acesso em 29 nov. 2014.

VICECONTI, P. E. V. Introdução à economia. 5. ed. São Paulo: Frase Editora, 2002. 